\title{
Soil Temperature and Phosphorus Supply Interactively Affect Physiological Responses of White Birch to $\mathrm{CO}_{2}$ Elevation
}

\author{
Gabriel Danyagri, Qing-Lai Dang*
}

Faculty of Natural Resources Management, Lakehead University, Thunder Bay, Ontario, Canada.

Email: ${ }^{*}$ dang@lakeheadu.ca

Received November $8^{\text {th }}, 2013$; revised December $12^{\text {th }}, 2013$; accepted January $8^{\text {th }}, 2014$

Copyright (C) 2014 Gabriel Danyagri, Qing-Lai Dang. This is an open access article distributed under the Creative Commons Attribution License, which permits unrestricted use, distribution, and reproduction in any medium, provided the original work is properly cited. In accordance of the Creative Commons Attribution License all Copyrights (C) 2014 are reserved for SCIRP and the owner of the intellectual property Gabriel Danyagri, Qing-Lai Dang. All Copyright (C) 2014 are guarded by low and by SCIRP as a guardian.

\section{ABSTRACT}

Phosphorus (P) is a common limiting nutrient element to plants and its supply and uptake by plants are strongly influenced by soil temperature. However, the interactive effects of the two factors on the physiological responses of plants to global change are poorly understood. In this study, we examined how $\mathbf{P}$ supply and $\mathbf{T}_{\text {soil }}$ interacted in affecting physiological responses in white birch (Betula papyrifera) to $\left[\mathrm{CO}_{2}\right]$. We exposed seedlings to $7^{\circ} \mathrm{C}, 17^{\circ} \mathrm{C}$ and $27^{\circ} \mathrm{C} \mathrm{T}_{\text {soil }}, 0.1479,0.3029$ and $0.5847 \mathrm{mM} \mathrm{P} \mathrm{P}_{5}$, and 360 and $720 \mu \mathrm{mol} \cdot \mathrm{mol}^{-1}\left[\mathrm{CO}_{2}\right.$ ] for four months. We have found that both the low soil temperature and $\mathrm{CO}_{2}$ elevation resulted in photosynthetic down regulation but the specific mechanisms of the down regulation were different between the two treatments, particularly the relative contributions of biochemical and photochemical capacity, mesophyll conductance and sink strength for carbohydrate utilization to the down regulation. Furthermore, our data suggest that morphological adjustments, such as reduced leaf size and total leaf area, were the primary form of responses in white birch to low phosphorus supply and no significant physiological acclimation to $\mathbf{P}$ supply was detected. Our results suggest that white birch will likely enhance water use efficiency under the projected future climate conditions with doubled carbon dioxide concentration, particularly at warmer soil temperatures. Although a trade-off between water use efficiency and nutrient use efficiency is widely accepted, our results suggest that there does not have to be a trade-off between the two, for instance, $\mathrm{CO}_{2}$ elevation increased both use efficiencies and low soil temperature and reduced nitrogen efficiency without affecting water use efficiency under elevated $\mathrm{CO}_{2}$.

\section{KEYWORDS}

Betula papyrifera Mash; Foliar Gas Exchange; Water-Use-Efficiency; Stomatal Conductance; Rubisco; Boreal Trees; Climate Change

\section{Introduction}

Photosynthetic carbon fixation by trees is the primary contributor to the total productivity of forest ecosystems. A good understanding of how increases in atmospheric $\mathrm{CO}_{2}$ concentration ( $\left[\mathrm{CO}_{2}\right]$ ) will affect the photosynthesis of trees will be critical for understanding how climate change will affect the structure, functioning and productivity of forest ecosystems. Photosynthetic responses to $\mathrm{CO}_{2}$ elevations can vary with species, the physiological

\footnotetext{
${ }^{*}$ Corresponding author.
}

conditions of plants and environmental conditions. For example, $\mathrm{CO}_{2}$ elevations generally result in a downregulation of photosynthetic capacity in plants that are nutrient-stressed [1-8]. Most studies have shown that nutrient deficiency reduces the benefits of $\mathrm{CO}_{2}$ elevation to plants $[2,6,7,9]$. However, past studies have generally focused on nitrogen because it generally is the most limiting nutrient element to plants in the field $[6,8,10,11]$. As another key nutrient element for photosynthesis, phosphorus $(\mathrm{P})$ is often the most limiting or second most limiting element to the aboveground primary productivity 
of forests [12]. However, the effect of P supply on photosynthetic response to $\mathrm{CO}_{2}$ is not well studied.

$\mathrm{P}$ is an essential element for some vital structural and metabolic functions of plants and its deficiency can reduce energy transfer and even lead to a breakdown of cell membranes [13]. P deficiency can limit photosynthesis either indirectly by reducing the total leaf area of a plant [14], or more directly by reducing Rubisco activity and RuBP regeneration [15-18]. Studies using isolated chloroplasts and other in-vitro systems show that $\mathrm{P}$ is involved in the activation of Rubisco [19], the modulation of ribulose-5-phosphate kinase and fructose-l,6-bisphosphate phosphatase [20], the transport of triosephosphate (TP) across the chloroplast membrane by the Pi-translocator and the regulation of photophosphorylation [21]. Rao and Terry [22] have found that a deficiency in inorganic phosphate (Pi) results in a substantial increase in non-stomatal limitation to photosynthesis. All of the above physiological processes can affect photosynthetic responses to $\mathrm{CO}_{2}$ elevation. Tissue and Lewis [23] have demonstrated that $\mathrm{P}$ deficiency reduces the positive effect of $\mathrm{CO}_{2}$ elevation on photosynthesis in cottonwood.

Soil temperature $\left(\mathrm{T}_{\text {soil }}\right)$ also affects plant responses to $\mathrm{CO}_{2}$ elevations. Low $\mathrm{T}_{\text {soil }}$ reduces root permeability and increases water viscosity, leading to a decrease in shoot water potential $(\Psi)$ and stomatal conductance $\left(\mathrm{g}_{\mathrm{s}}\right)[5,24$, 25]. Reductions in $g_{s}$ and shoot water potential in turn can affect photosynthetic responses to $\mathrm{CO}_{2}$ elevation [5, 25]. For example, low $T_{\text {soil }}$ is found to reduce the positive effect of $\mathrm{CO}_{2}$ elevations on photosynthesis in various tree species [5,26-29]. Low $T_{\text {soil }}$ can also reduce the synergistic effect of $\mathrm{CO}_{2}$ elevation and high $\mathrm{N}$ supply on photosynthesis [28] and growth [29]. However, the decline in $\mathrm{g}_{\mathrm{s}}$ at low $\mathrm{T}_{\text {soil }}$ does not necessarily lead to a reduction in photosynthesis in all species [30,31]. Furthermore, low $\mathrm{T}_{\text {soil }}$ has also been observed to reduce the absorption of mineral nutrients directly and/or indirectly by reducing root growth [32-35] or mycorrhizal formation [36]. The availability and absorption of $\mathrm{P}$ are particularly sensitive to soil temperature in the boreal forest where it is primarily absorbed through mycorrhizae because of the immobility of the element [25]. However, it is not clear how P supply and soil temperature will interact in affecting tree's physiological responses to $\mathrm{CO}_{2}$ elevations. As the global warming progresses in response to increasing atmospheric $\left[\mathrm{CO}_{2}\right]$ and other greenhouse gases, changes in $\mathrm{T}_{\text {soil }}$ will be inevitable because of changes in the depth and duration of snow cover and soil freezing [37]. However, soil warming generally lags behind changes in air temperature. Low $\mathrm{T}_{\text {soil }}$ is prevalent in the boreal forest, particularly at sites with poor drainage and northern and eastern slopes $[38,39]$. The combination of warmer air temperature and cold soil may severely constrain the response of boreal forests to climate change. Low $\mathrm{T}_{\text {soil }}$ may have been a contributing factor to the wide spread damages to boreal trees by unseasonal warm temperatures [40].

A better understanding of the interactive effects of $P$ supply and $\mathrm{T}_{\text {soil }}$ on the physiological responses of trees to $\mathrm{CO}_{2}$ elevations will be critical for predicting the potential responses of boreal forests to climate changes associated with rising atmospheric $\left[\mathrm{CO}_{2}\right]$. This study investigates the interactive effects of P supply and soil temperature on the physiological responses of white birch (Betula papyrifera Marsh) to the doubling of atmospheric $\mathrm{CO}_{2}$ concentration. Since low soil temperature restricts $\mathrm{P}$ absorption by roots and $\mathrm{P}$ deficiency can lead to photosynthetic down regulation at elevated $\left[\mathrm{CO}_{2}\right]$, we hypothesize that low $\mathrm{T}_{\text {soil }}$ will result in a greater degree of photosynthetic down-regulation under elevated $\left[\mathrm{CO}_{2}\right]$, particularly when $\mathrm{P}$ supply is low.

\section{Materials and Methods}

\subsection{Plant Materials}

The experiment was conducted at the Thunder Bay campus of Lakehead University. White birch seeds were collected from the boreal forest near Thunder Bay and germinated in horticultural trays $(28 \mathrm{~cm} \times 56 \mathrm{~cm})$ filled with a mixture of Sphagnum peat moss and horticultural vermiculite (2:1 by volume). This composition has a very high cation exchange, low inherent fertility, a slightly acidic $\mathrm{pH}$ (maximizing the availability of all nutrient elements) and a good balance of water holding and aeration porosity [41]. Seedlings of relatively uniform height were transplanted into PVC containers $(31.5 \mathrm{~cm}$ deep, $11 / 9.5 \mathrm{~cm}$ top/bottom diameter) after 4 weeks of germination and moved to treatment greenhouses as described below.

\subsection{Experimental Design}

The experiment was a split-split-plot design consisting of two $\mathrm{CO}_{2}$ concentrations (360 ambient vs. 720 elevated $\mu \mathrm{mol} \cdot \mathrm{mol}^{-1}$, main plot), three $\mathrm{T}_{\text {soil }}$ (split plot) nested within each $\mathrm{CO}_{2}$ treatment $\left(7^{\circ} \mathrm{C}, 17^{\circ} \mathrm{C}\right.$ and $\left.27^{\circ} \mathrm{C}\right)$ and three levels of $\mathrm{P}$ supply (split-split plot) nested within each $\mathrm{T}_{\text {soil }}\left(0.1479,0.3029\right.$ and $0.5847 \mathrm{mM} \mathrm{P}_{2} \mathrm{O}_{5}$, or 0.2958, 0.6058 and $1.1694 \mathrm{mM} \mathrm{P}$ ). The soil temperatures and P levels were determined based on the field conditions within the ecological range of the species. Nitrogen and potassium concentrations were 221 and $150 \mathrm{mg} / \mathrm{L}$, respectively, in all treatments. There were two independent replications (greenhouses) for each $\mathrm{CO}_{2}$ treatment, i.e., four separate greenhouses were used. There were eight seedlings per treatment combination. The soil temperature control system consisted of a large box with plant pots mounted and sealed to the bottom and each pot had a 1/2"-diameter drainage hole in the middle. $T_{\text {soil }}$ was 
regulated by circulating temperature-controlled water in the space between seedling pots within the large box. The box was insulated to minimize the influence of air temperature on $\mathrm{T}_{\text {soil }}$. Further details on the soil temperature control system can be found in [42]. The day/night temperatures were $20^{\circ} \mathrm{C}-26^{\circ} \mathrm{C} / 15^{\circ} \mathrm{C}-18^{\circ} \mathrm{C}$ and the photoperiod was 16 hours in all the treatments. All the seedlings were fertilized twice a week with $0.5 \mathrm{~L}$ fertilizer solution (which saturated the growing medium). The seedlings were watered frequently to maintain the volumetric water content of the growing medium above $30 \%$ as measured with an HH2 moisture meter and a Theta probe (Delta-T Devices Ltd., Cambridge, UK). The temperature of the fertilizer solution and irrigation water was adjusted to the corresponding treatment $\mathrm{T}_{\text {soil }}$.

White birch is a shade intolerant tree species [43]. It can grow to its full potential under $45 \%$ of full sunlight or above. It is very sensitive to moisture, temperature, nutrient and light conditions during the seedling stage. Its seasonal growth can start while daily minimum temperature is below freezing. Seedling height growth can be prolonged indefinitely under long photoperiods [43].

\subsection{Gas Exchange Measurements}

Six seedlings per treatment combination were randomly selected for measuring photosynthetic response curves to $\left[\mathrm{CO}_{2}\right]$ after four months of treatment. The measurements were taken using a CIRAS-1 open gas exchange system with an automatic environment control leaf chamber (PP-Systems, Hitchin Hertfordshire, UK) on the first unshaded mature leaf from the top of the seedling $\left(3^{\text {rd }}\right.$ to $5^{\text {th }}$ from the tip). All measurements were taken between 0900 and $1200 \mathrm{hr}$ when gas exchange variables were stable. The environmental conditions in the leaf chamber were as follows: $50 \% \mathrm{RH}, 800 \mu \mathrm{mol} \mathrm{m}{ }^{-2} \cdot \mathrm{s}^{-1}$ PAR and 26 ${ }^{\circ} \mathrm{C}$ leaf temperatures. The $\mathrm{A} / \mathrm{C}_{\mathrm{i}}$ response curve was measured at 50,100,150, 250, 300, 500, 700, 900 and $1500 \mu \mathrm{mol} \cdot \mathrm{mol}^{-1} \mathrm{CO}_{2}$. The rate of net photosynthesis at the corresponding growth $\left[\mathrm{CO}_{2}\right]$ (i.e., 720 and 360 $\mu \mathrm{mol} \cdot \mathrm{mol}^{-1}$ for the elevated and ambient $\mathrm{CO}_{2}$ treatment, respectively) $\left(\mathrm{P}_{\mathrm{n}}\right)$ and the rate at $360 \mu \mathrm{mol} \cdot \mathrm{mol}^{-1}\left[\mathrm{CO}_{2}\right]$ for both $\mathrm{CO}_{2}$ treatments $\left(\mathrm{P}_{\mathrm{n} 360}\right)$, transpiration rate and stomatal conductance $\left(\mathrm{g}_{\mathrm{s}}\right.$ ) were estimated from the response curve of the relevant parameter to measurement $\left[\mathrm{CO}_{2}\right]$. Photosynthetic water use efficiency was calculated as IWUE $=\mathrm{P}_{\mathrm{n}}$ /transpiration. The rate of in vivo maximal Rubisco carboxylation $\left(\mathrm{V}_{\mathrm{cmax}}\right)$, rate of photosynthetic electron transport (J), triose-phosphate utilization (TPU) and mesophyll conductance $\left(\mathrm{g}_{\mathrm{m}}\right)$ were calculated using the $\mathrm{A} / \mathrm{Ci}$ Curve Fitting Utility version 1.1 developed by Sharkey et al. (2007).

\subsection{Leaf Nutrient $(\mathbf{N}, \mathbf{P}, \mathbf{K})$ Assays}

Total foliar nitrogen was analyzed using the LECO CNS
2000 dry combustion method [44] and P and $\mathrm{K}$ were analyzed using nitric/hydrochloric acid digestion method $[45,46]$. The nutrient concentrations were expressed on the basis of leaf area and leaf mass. Photosynthetic Nitrogen- and P-use efficiencies (hereafter referred to as NUE and PUE, respectively) were calculated by dividing $\mathrm{P}_{\mathrm{n}}$ by the corresponding leaf area-based concentration.

\subsection{Data Analysis}

The Analysis of Variance (ANOVA) were conducted using the Data Desk 6.0 statistical package (Data Description, Ithaca, NY) on the original variables (i.e., no data transformation) since tests showed both ANOVA assumptions (i.e., normality and homogeneity) were satisfied. When a factor with more than two levels (i.e., $\mathrm{T}_{\text {soil }}$ and $\mathrm{P}$ ) or an interaction was significant, multiple comparisons were conducted using the Least Square Difference (LSD) method. Because of the relatively small sample size in this study and consequently small degree of freedom for the experiment error in the $\mathrm{F}$ test (leading to a larger denominator in F calculation), it is more likely for true treatment effects go undetected (Type II error) $[47,48]$. Therefore we considered a probability above 0.05 but below 0.10 as marginally significant but the interpretation of such results was taken with great precaution. Such a practice is also used in other studies (e.g., [48-50]. However, we have presented the actual probability values in both figures and tables so that the readers can make their own judgement.

\section{Results}

\subsection{Gas Exchange}

The $\mathrm{CO}_{2}$ elevation significantly increased the photosynthetic rate $\left(\mathrm{P}_{\mathrm{n}}\right)$ at the corresponding treatment $\left[\mathrm{CO}_{2}\right]$ but reduced $\mathrm{P}_{\mathrm{n} 360}$ (Table 1, Figure $1(\mathrm{~A})$ ). The low $\mathrm{T}_{\text {soil }}$ significantly reduced $P_{n}$ and $P_{n 360}$ but there were no significant differences found between the intermediate and high $\mathrm{T}_{\text {soil }}$ at either $\mathrm{CO}_{2}$ treatment (Table 1, Figures 1(A) and (B)).

The $\mathrm{CO}_{2}$ elevation significantly reduced the stomatal conductance $\left(g_{\mathrm{s}}\right)$ at the intermediate and high but not at the low $\mathrm{T}_{\text {soil }}$ (Table 1, Figure $1(\mathrm{C})$ ). $\mathrm{T}_{\text {soil }}$ had similar effects on $g_{s}$ as it did on $P_{n}$ and $P_{n 360}$ under the ambient $\left[\mathrm{CO}_{2}\right]$ but had no significant effect found on $\mathrm{g}_{\mathrm{s}}$ under the elevated $\left[\mathrm{CO}_{2}\right]$ (Table 1, Figures $1(\mathrm{~A})-(\mathrm{C})$ ).

The photosynthetic water use efficiency (IWUE) decreased with increasing $\mathrm{T}_{\text {soil }}$ under the ambient $\left[\mathrm{CO}_{2}\right]$ but was not significantly influenced by $\mathrm{T}_{\text {soil }}$ under the elevated $\left[\mathrm{CO}_{2}\right]$ (Table 1, Figure $1(\mathrm{D})$ ). The $\mathrm{CO}_{2}$ elevation significantly increased IWUE at the intermediate and high but not at the low $\mathrm{T}_{\text {soil }}$ (Figure 1(D), Table 1).

The soil temperature effect on the mesophyll conductance to $\mathrm{CO}_{2}\left(\mathrm{~g}_{\mathrm{m}}\right)$ differed between the two $\mathrm{CO}_{2}$ treat- 
Table 1. Probabilities from ANOVA for the effects of soil temperature $\left(\mathrm{T}_{\text {soil }}\right)$, phosphorus supply $(\mathrm{P})$ and $\left[\mathrm{CO}_{2}\right]$ on net photosynthetic rate at growth $\left[\mathrm{CO}_{2}\right]\left(\mathrm{P}_{\mathrm{n}}\right)$, photosynthetic rate measured at a common $\left[\mathrm{CO}_{2}\right]\left(\mathrm{P}_{\mathrm{n} 360}\right)$, stomatal conductance to water $\left(g_{s}\right)$, instantaneous water-use-efficiency (IWUE), mesophyll conductance to $\mathrm{CO}_{2}\left(\mathrm{~g}_{\mathrm{m}}\right)$, intercellular/atmospheric $\left[\mathrm{CO}_{2}\right]$ ratio at the growth $\left[\mathrm{CO}_{2}\right](\mathrm{Ci} / \mathrm{Ca})$, maximum rate of carboxylation $\left(\mathrm{V}_{\mathrm{cmax}}\right)$, rate of photosynthetic electron transport $(\mathrm{J})$ and trios-phosphate utilization (TPU) in white birch seedlings. The seedlings were grown at 360 and $720 \mu \mathrm{mol}^{\circ} \mathrm{mol}^{-1}\left[\mathrm{CO}_{2}\right] ; 7^{\circ} \mathrm{C}$ $17^{\circ} \mathrm{C}$ and $27^{\circ} \mathrm{C} \mathrm{T}_{\text {soil }}$ and 241,493 and $951 \mathrm{mg} / \mathrm{L} P$ supply. The soil temperatures and $P$ levels were determined based on the field conditions within the ecological range of the species. Significant probabilities were bold-faced.

\begin{tabular}{cccccccc}
\hline Source of variation & $\mathrm{CO}_{2}$ & $\mathrm{~T}_{\text {soil }}$ & $\mathrm{CO}_{2} \times \mathrm{T}_{\text {soil }}$ & $\mathrm{P}$ & $\mathrm{CO}_{2} \times \mathrm{P}$ & $\mathrm{T}_{\text {soil }} \times \mathrm{P}$ & $\mathrm{CO}_{2} \times \mathrm{T}_{\text {soil }} \times \mathrm{P}$ \\
\hline $\mathrm{P}_{\mathrm{n}}$ & $\mathbf{0 . 0 1 8 4}$ & $\mathbf{0 . 0 0 8 4}$ & 0.9429 & 0.4129 & 0.8592 & 0.873 & 0.6331 \\
$\mathrm{P}_{\mathrm{n} 360}$ & $<\mathbf{0 . 0 0 0 1}$ & $\mathbf{0 . 0 2 5 8}$ & 0.2246 & 0.4950 & 0.9930 & 0.9209 & 0.9887 \\
$\mathrm{~g}_{\mathrm{s}}$ & $\mathbf{0 . 0 0 9 1}$ & $\mathbf{0 . 0 1 0 3}$ & 0.0652 & 0.9889 & 0.8845 & 0.9918 & 0.9492 \\
$\mathrm{IWUE}$ & $\mathbf{0 . 0 0 1 2}$ & $\mathbf{0 . 0 3 0 6}$ & 0.0825 & 0.9512 & 0.9921 & 0.9826 & 0.8020 \\
$\mathrm{~g}_{\mathrm{m}}$ & 0.7440 & $\mathbf{0 . 0 0 0 8}$ & $\mathbf{0 . 0 1 7 7}$ & 0.9688 & 0.9233 & 0.4105 & 0.9202 \\
$\mathrm{Ci} / \mathrm{Ca}$ & 0.1964 & 0.5460 & 0.4202 & 0.9188 & 0.4634 & 0.4663 & 0.8509 \\
$\mathrm{~V}_{\text {cmax }}$ & 0.0620 & 0.1321 & $\mathbf{0 . 0 5 8 4}$ & $\mathbf{0 . 0 7 3 3}$ & 0.2427 & 0.4141 & 0.5745 \\
$\mathrm{~J}$ & 0.1457 & $\mathbf{0 . 0 0 0 2}$ & $\mathbf{0 . 0 3 9 9}$ & 0.1755 & 0.5823 & 0.2122 & 0.6157 \\
$\mathrm{TPU}$ & 0.1096 & $\leq \mathbf{0 . 0 0 0 1}$ & 0.1209 & $\mathbf{0 . 0 2 8 6}$ & 0.3036 & 0.4961 & 0.4485 \\
\hline
\end{tabular}

ments: at the ambient $\left[\mathrm{CO}_{2}\right], \mathrm{g}_{\mathrm{m}}$ was the lowest at the low $\mathrm{T}_{\text {soil }}$ while there were no significant differences between the other two $\mathrm{T}_{\text {soil }}$; at the elevated $\left[\mathrm{CO}_{2}\right]$, $\mathrm{g}_{\mathrm{m}}$ was the lowest at the high $\mathrm{T}_{\text {soil }}$ and highest at the intermediate $\mathrm{T}_{\text {soil }}$ (Figure 2(A)). The $\mathrm{CO}_{2}$ elevation significantly increased $g_{m}$ at the low $T_{\text {soil }}$ but had no significant effect at other temperatures (Figure 2(A)). The internal to ambient $\mathrm{CO}_{2}$ concentration ratio at the corresponding growth $\left[\mathrm{CO}_{2}\right](\mathrm{Ci} / \mathrm{Ca})$ was not significantly affected by any of the treatments (Table 1 ).

\subsection{In Vivo Biochemical and Rubisco Activities}

Both the maximum rate of Rubisco carboxylation $\left(\mathrm{V}_{\mathrm{cmax}}\right)$ and the rate of photosynthetic electron transport $(\mathrm{J})$ had the highest value at the intermediate $T_{\text {soil }}$ while there were not significantly differences between the low and high Tsoil at the ambient $\left[\mathrm{CO}_{2}\right]$ (Table 1, Figures 2(B) and $(\mathrm{C}))$. At the elevated $\left[\mathrm{CO}_{2}\right]$, in contrast, $\mathrm{T}_{\text {soil }}$ did not significantly affect $\mathrm{V}_{\text {cmax }}$ but $\mathrm{J}$ was significantly lower at the high than at the intermediate $\mathrm{T}_{\text {soil }}$ (Figure 2(C)). The $\mathrm{CO}_{2}$ elevation significantly reduced $\mathrm{V}_{\mathrm{cmax}}$ only at the intermediate $\mathrm{T}_{\text {soil }}$ and $\mathrm{J}$ at both intermediate and high $\mathrm{T}_{\text {soil }}$ (Figures 2(B) and (C)). Furthermore, $V_{\text {cmax }}$ generally increased with increasing $P$ supply but the effect was not statistically significant at $0.05 \mathrm{P}$ level. Although the $\mathrm{P}$ effect appeared to be affected by $\left[\mathrm{CO}_{2}\right]$ and $\mathrm{T}_{\text {soil }}$, the interactions were not statistically significant (Figure 2(B), Table 1).

The low $\mathrm{T}_{\text {soil }}$ significantly reduced the rate of triose phosphate utilization (TPU) (Table 1, Figure 2(D)). TPU generally increased with increasing $\mathrm{P}$ supply but the difference between the low and intermediate $\mathrm{P}$ levels was not statistically significant (Figure 2(D)).

\subsection{Foliar Nutrient Concentrations and Nutrient Use-Efficiencies}

The low $\mathrm{T}_{\text {soil }}$ significantly reduced leaf $\mathrm{K}$ concentrations at the ambient but not at the elevated $\left[\mathrm{CO}_{2}\right]$ (Table 2, Figures 3(A) and (B)). The $\mathrm{CO}_{2}$ elevation significantly reduced foliar $\mathrm{K}$ concentrations at the intermediate and high but not at the low $\mathrm{T}_{\text {soil }}$ (Figures $3(\mathrm{~A})$ and (B)). Mass based foliar $\mathrm{K}$ concentration increased with increasing $\mathrm{P}$ supply (Figure 3(A)).

The low $\mathrm{T}_{\text {soil }}$ significantly reduced both mass based $\left(\mathrm{P}_{\mathrm{m}}\right)$ and leaf area based $\mathrm{P}$ concentration $\left(\mathrm{P}_{\mathrm{a}}\right)$ under the ambient $\left[\mathrm{CO}_{2}\right]$ but not under the elevated $\left[\mathrm{CO}_{2}\right]$ (Table 2, Figures $3(\mathrm{C})$ and (D)). The $\mathrm{CO}_{2}$ elevation significantly reduced both $\mathrm{P}_{\mathrm{m}}$ and $\mathrm{P}_{\mathrm{a}}$ at the intermediate and high $\mathrm{T}_{\text {soil }}$ but not at the low $\mathrm{T}_{\text {soil }}$ (Figures $3(\mathrm{C})$ and (D)). As with $\mathrm{K}_{\mathrm{m}}, \mathrm{P}_{\mathrm{m}}$ at all three Tsoil and $\mathrm{P}_{\mathrm{a}}$ at the intermediate and high $\mathrm{T}_{\text {soil }}$ increased with increasing $\mathrm{P}$ supply (Figures 3(C) and (D)); The low $\mathrm{T}_{\text {soil }}$ decreased $\mathrm{P}_{\mathrm{m}}$ at all three $\mathrm{P}$ levels (Figure $3(C)$ ) while it reduced $\mathrm{P}_{\mathrm{a}}$ only in the high $\mathrm{P}$ treatment (Figure 3(D)).

$\mathrm{N}_{\mathrm{m}}$ generally increased with increasing $\mathrm{P}$ supply under the ambient $\left[\mathrm{CO}_{2}\right]$ and high $\mathrm{T}_{\text {soil }}$ while there was no clear trend in other treatment combinations (Table 2, Figure $3(E)$ ). The $\mathrm{CO}_{2}$ elevation generally decreased $\mathrm{N}_{\mathrm{m}}$ with some minor variations with $\mathrm{P}$ and $\mathrm{T}_{\text {soil }}$ (no clear patterns, Figure $3(\mathrm{E})$ ). The effects of $\mathrm{T}_{\text {soil }}$ also varied with $\left[\mathrm{CO}_{2}\right]$ and $\mathrm{P}$ levels but did not show clear general patterns except the low $\mathrm{T}_{\text {soil }}$ reduced $\mathrm{N}_{\mathrm{m}}$ at the low $\mathrm{P}$ level under elevated $\left[\mathrm{CO}_{2}\right]$ (Figure $3(\mathrm{E})$ ). $\mathrm{N}_{\mathrm{a}}$ was the highest at low $\mathrm{P}$ and lowest at the high $\mathrm{P}$ under the low $\mathrm{T}_{\text {soil }}$ but 


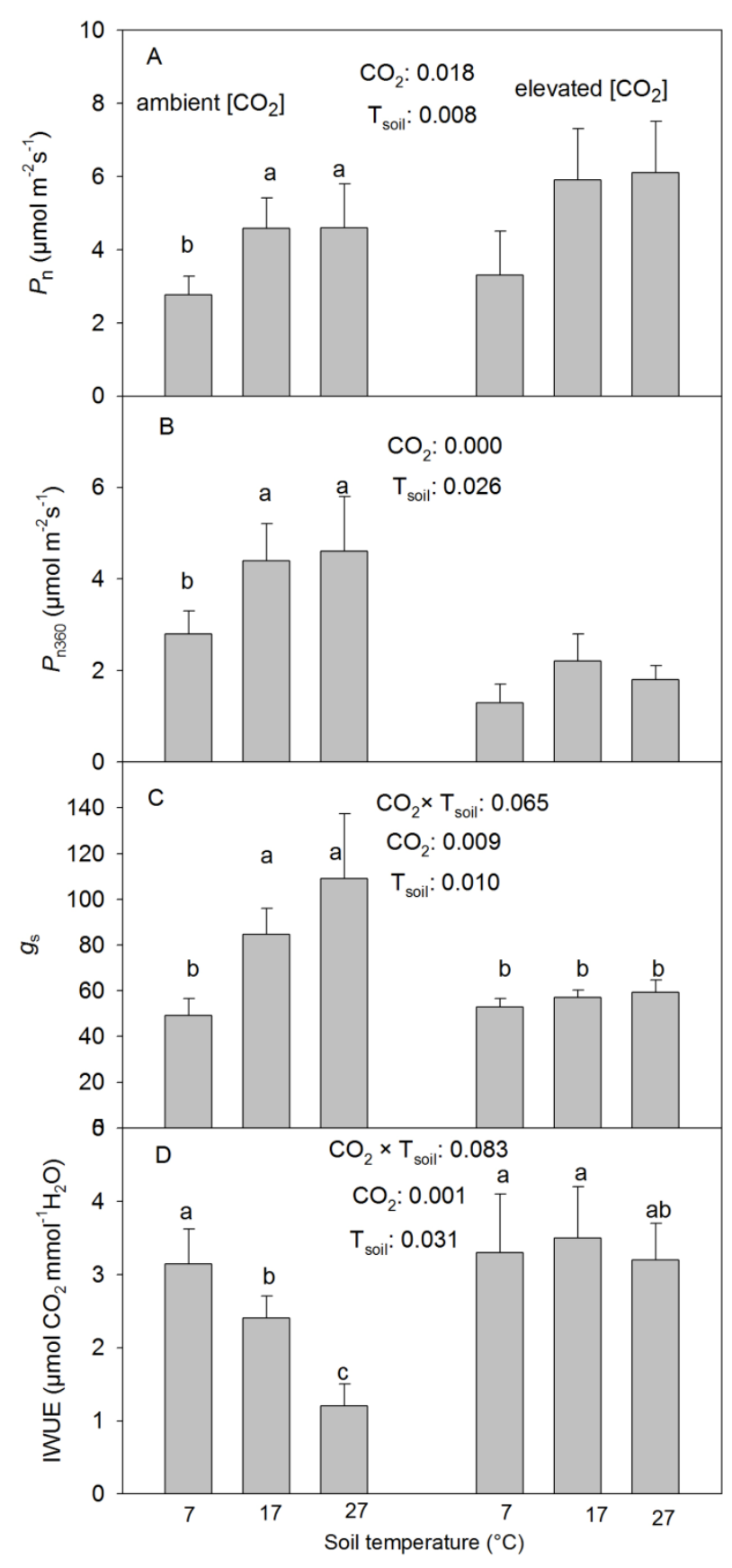

Figure 1. Effects of $\mathrm{CO}_{2}$ concentration and soil temperature $\left(T_{\text {soil }}\right)$ on the rate of net photosynthesis at growth $\mathrm{CO}_{2}\left(\mathrm{P}_{n}\right)$ and the rate measured at a common ambient $\mathrm{CO}_{2}$ concentration $\left(\mathbf{P}_{\mathrm{n} 360}\right)$, stomatal conductance to water $\left(\mathrm{g}_{\mathrm{s}}\right)$ and instantaneous water-use-efficiency (IWUE) (mean + SE, $n=6$ ) in white birch seedlings. The seedlings were grown under two $\left[\mathrm{CO}_{2}\right]\left(360\right.$ and $\left.720 \mu \mathrm{mol} \cdot \mathrm{mol}^{-1}\right)$, three $\mathrm{T}_{\text {soil }}\left(7^{\circ} \mathrm{C}, 17^{\circ} \mathrm{C}\right.$ and $27^{\circ} \mathrm{C}$ ) and 3 levels of $P$ supply $(0.1479,0.3029$ and $0.5847 \mathrm{mM} \mathrm{P}_{2} \mathrm{O}_{5}$ ). Means with the same letter(s) over them are not significantly different from one another $(p>0.10)$. Only significant treatments were labeled. $T_{\text {soil }}$ effects are labeled only on the side of the ambient $\left[\mathrm{CO}_{2}\right]$ since there were no significant interactions between $\mathrm{CO}_{2}$ and $\mathrm{T}_{\text {soil }}(\mathrm{p}>$ 0.10). ${ }^{* * *}: \mathbf{p} \leq 0.01 ; * * 0.01<\mathbf{p} \leq 0.05 ; *: 0.05<\mathbf{p} \leq 0.10$.

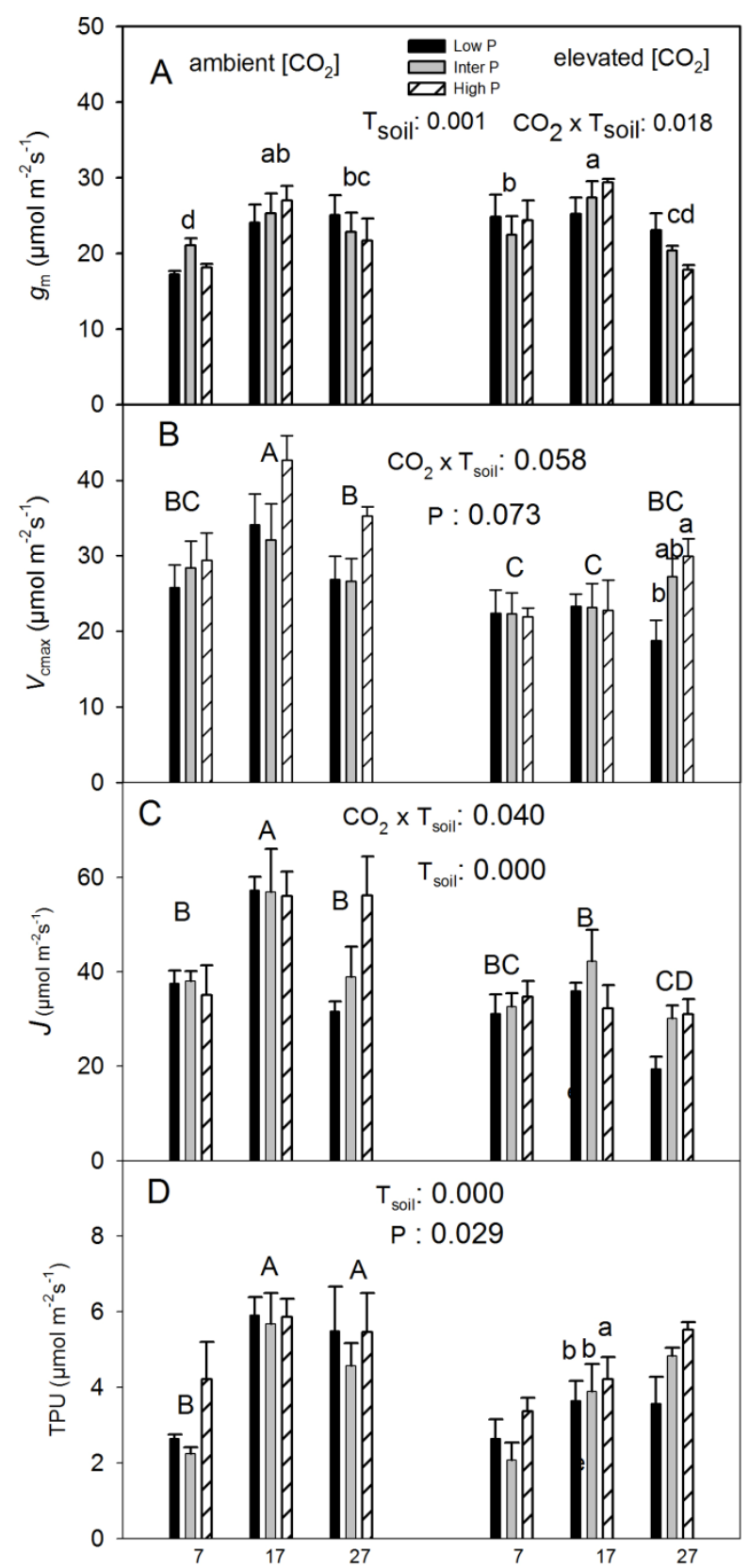

Figure 2. Effects of $\mathrm{CO}_{2}, \mathrm{~T}_{\text {soil }}$ and $\mathrm{P}$ on mesophyll conductance to $\mathrm{CO}_{2}\left(\mathrm{~g}_{\mathrm{m}}\right)$, maximum rate of carboxylation $\left(\mathrm{V}_{\mathrm{cmax}}\right)$, rate of photosynthetic electron transport $(\mathrm{J})$ and rate of triose-phosphate utilization (TPU) in white birch seedlings. Means with the same letter(s) or number(s) are not significantly different from each other $(p>0.10)$. Other explanations are as in Figure 1.

the trend was the opposite at other $\mathrm{T}_{\text {soil }}$ Table 2, Figure $3(\mathrm{~F})$ ). The $\mathrm{CO}_{2}$ elevation significantly reduced $\mathrm{N}_{\mathrm{a}}$ (Table 2, Figure $3(\mathrm{~F})$ ).

The $\mathrm{CO}_{2}$ elevation significantly increased both photosynthetic phosphorus use-efficiency (PUE) and photosynthetic nitrogen use-efficiency (NUE) (Table 2, Figures $3(\mathrm{G})$ and $(\mathrm{H})$ ). The low $\mathrm{T}_{\text {soil }}$ significantly reduced 


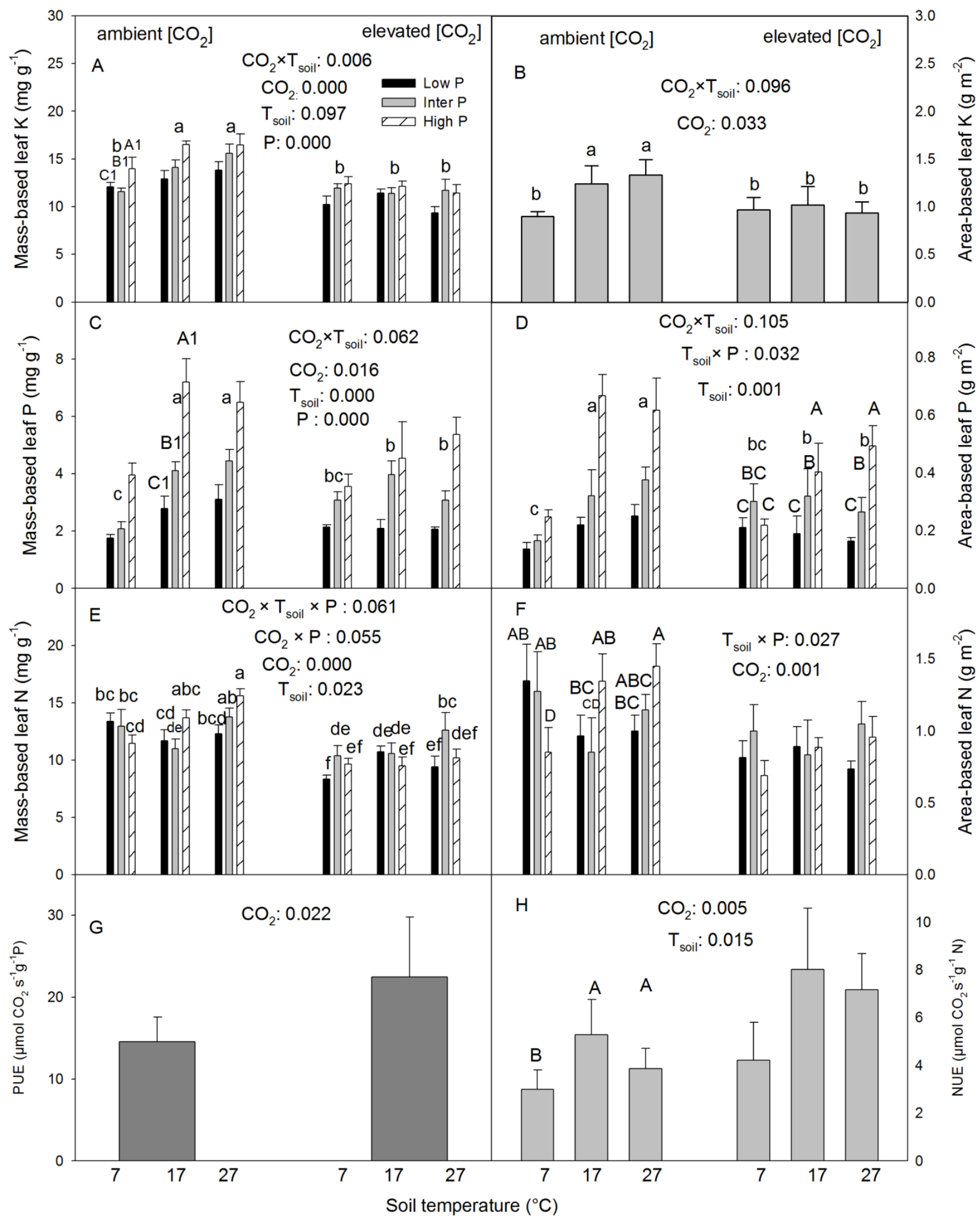

Figure 3. Effects of $\mathrm{CO}_{2}, \mathrm{~T}_{\text {soil }}$ and $P$ on foliar nutrient concentrations and photosynthetic $\mathrm{N}$ and $\mathrm{P}$ use efficiency in white birch seedlings. Non-significant effects were pooled in Figures $B, G$ and $\mathbf{H}$ to provide a clearer presentation of significant effects. In Figure D, upper case letters indicate $T_{\text {soil }} \times \mathbf{P}$ interactions while lower case letters are for $\mathrm{CO}_{2} \times \mathrm{T}_{\text {soil }}$ interactions. Other explanations are as in Figures 1 and 2. 
Table 2. Probabilities from ANOVA for the effects of $\mathbf{T}_{\text {soil }}$, $\mathbf{P}$ supply and $\left[\mathrm{CO}_{2}\right]$ on mass-based leaf potassium concentration $\left(K_{m}\right)$, area-based leaf potassium concentration $\left(K_{\mathrm{a}}\right)$, mass-based leaf phosphorus concentration $\left(P_{m}\right)$, area-based leaf phosphorus concentration $\left(P_{a}\right)$, mass-based leaf nitrogen concentration $\left(N_{m}\right)$, area-based leaf nitrogen concentration $\left(N_{a}\right)$, photosynthetic phosphorus use-efficiency (PUE), nitrogen use efficiency (NUE) and total leaf area per seedling in white birch. Other explanations are as in Table 1.

\begin{tabular}{cccccccc}
\hline Source of variation & $\mathrm{CO}_{2}$ & $\mathrm{~T}_{\text {soil }}$ & $\mathrm{CO}_{2} \times \mathrm{T}_{\text {soil }}$ & $\mathrm{P}$ & $\mathrm{CO}_{2} \times \mathrm{P}$ & $\mathrm{T}_{\text {soil }} \times \mathrm{P}$ & $\mathrm{CO}_{2} \times \mathrm{T}_{\text {soil }} \times \mathrm{P}$ \\
\hline $\mathrm{K}_{\mathrm{m}}$ & $<\mathbf{0 . 0 0 0 1}$ & $\mathbf{0 . 0 9 6 7}$ & $\mathbf{0 . 0 0 6 4}$ & $\mathbf{0 . 0 0 0 2}$ & 0.2653 & 0.6605 & 0.6798 \\
$\mathrm{~K}_{\mathrm{a}}$ & $\mathbf{0 . 0 3 2 9}$ & 0.1265 & $\mathbf{0 . 0 9 5 6}$ & 0.1215 & 0.3877 & 0.1349 & 0.9885 \\
$\mathrm{P}_{\mathrm{m}}$ & $\mathbf{0 . 0 1 6 0}$ & $\mathbf{0 . 0 0 0 3}$ & $\mathbf{0 . 0 6 1 8}$ & $<\mathbf{0 . 0 0 0 1}$ & 0.1649 & 0.3363 & 0.4456 \\
$\mathrm{P}_{\mathrm{a}}$ & 0.1410 & $\mathbf{0 . 0 0 1 2}$ & $\mathbf{0 . 1 0 4 6}$ & $<\mathbf{0 . 0 0 0 1}$ & 0.1378 & $\mathbf{0 . 0 3 1 6}$ & 0.6929 \\
$\mathrm{~N}_{\mathrm{m}}$ & $<\mathbf{0 . 0 0 0 1}$ & 0.0234 & 0.3268 & 0.1756 & 0.0548 & 0.1137 & $\mathbf{0 . 0 6 0 9}$ \\
$\mathrm{N}_{\mathrm{a}}$ & $\mathbf{0 . 0 0 1 4}$ & 0.6367 & 0.7479 & 0.7249 & 0.4644 & $\mathbf{0 . 0 2 7 1}$ & 0.5478 \\
$\mathrm{PUE}$ & $\mathbf{0 . 0 2 1 8}$ & 0.2474 & 0.2109 & 0.1773 & 0.9743 & 0.7295 & 0.9954 \\
$\mathrm{NUE}$ & 0.0051 & 0.0146 & 0.5792 & 0.2863 & 0.4205 & 0.3170 & 0.7479 \\
\hline
\end{tabular}

the NUE (Table 2, Figure 3(H)).

\section{Discussion}

Both the $\mathrm{CO}_{2}$ elevation and low soil temperature led to photosynthetic down-regulation in white birch but the physiological mechanisms of the down-regulation differed. Photosynthetic measurements at $360 \mu \mathrm{mol} \cdot \mathrm{mol}^{-1}$ $\mathrm{CO}_{2}$ suggest that both the low $\mathrm{T}_{\text {soil }}$ and $\mathrm{CO}_{2}$ elevation caused a down-regulation of photosynthesis, but the physiological processes/traits associated with the down regulation were different between the two treatments. While the declines in stomatal conductance contributed to photosynthetic down regulation in both treatments, weakness in sink strength for the utilization of photosynthates (as indicated by the rate of triose phosphate utilization,) was only a contributing factor in the low soil temperature treatment. The contributions of mesophyll conductance and biochemical and photochemical capacity to photosynthetic down regulation were complicated by the interactions between $\mathrm{CO}_{2}$ and soil temperature. For example,

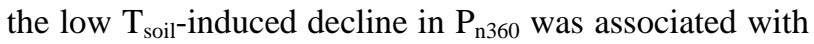
declines in mesophyll conductance under the ambient $\left[\mathrm{CO}_{2}\right]$, but not under the elevated $\left[\mathrm{CO}_{2}\right]$. The $\mathrm{CO}_{2}$ elevation resulted in significant declines in the maximum rate of Rubisco carboxylation, photosynthetic electronic transport and mesophyll conduction in some but not all soil temperatures.

The effects of low $\mathrm{T}_{\text {soil }}$ on foliar gas exchange are complicated, involving interactions between belowground and above-ground parts of the plant [5,24,25]. Larger sample sizes and more comprehensive diagnostic measurements including the measurement of additional characteristics (such as chlorophyll fluorescence parameters, analyses of water relations) may be necessary to discern the physiological mechanisms governing the changes in photosynthesis in response to the above two situations. Regardless of the mechanisms, the photosynthetic acclimation to elevated $\mathrm{CO}_{2}$ was partial since the photosynthetic rates measured under the corresponding growth $\mathrm{CO}_{2}$ concentration were significantly greater under the elevated than under the ambient $\mathrm{CO}_{2}$ concentration. A complete acclimation would have resulted in a photosynthetic rate at the elevated $\left[\mathrm{CO}_{2}\right]$ being equal to that at the ambient $\left[\mathrm{CO}_{2}\right]$.

The conclusions of photosynthetic down regulation varied with the specific parameters used in this study. Photosynthetic down regulation is assessed using several different variables in the literature. The maximum rate of Rubisco carboxylation $\left(\mathrm{V}_{\mathrm{cmax}}\right)$ and maximum rate of photosynthetic electron transport $(\mathrm{J})$ are often used to indicate changes in the biochemical capacity and photochemical capacity of the photosynthetic machinery [2,5, $7,51,52]$. Although there was a decline in both parameters associated with the low soil temperature under the ambient $\mathrm{CO}_{2}$ in this study, it was not the case under elevated $\mathrm{CO}_{2}$; furthermore, there was no decline in $\mathrm{V}_{\mathrm{cmax}}$ or $\mathrm{J}$ in response to the $\mathrm{CO}_{2}$ elevation. $\mathrm{P}_{\mathrm{n} 360}$ is often used as an indicator of the integrated acclimation of photosynthetic capacity and stomatal conductance $[8,52,53]$. To a certain degree, differences in $\mathrm{P}_{\mathrm{n} 360}$ reflect a shift in both the supply function and demand function of photosynthesis [25]. However, as discussed previously, the changes in $\mathrm{P}_{\mathrm{n} 360}$ in this study primarily reflect changes in the supply function, i.e., the effects of stomatal conductance. These results suggest that $\mathrm{P}_{\mathrm{n} 360}$ can be used to indicate the magnitude of photosynthetic down regulation but offers no clue to the mechanisms responsible for the down regulation unless it is considered in conjunction with other parameters. Moreover, $\mathrm{P}_{\mathrm{n} 360}$ will not be of any use for predicting photosynthetic performance under a future climate with a doubled atmospheric $\mathrm{CO}_{2}$ concen- 
tration because plants will not likely experience the present atmospheric $\mathrm{CO}_{2}$ concentration in the future once the $\mathrm{CO}_{2}$ concentration in the atmosphere is doubled.

The data suggest that white birch will likely have higher water use efficiency (WUE) in the future under elevated atmospheric $\mathrm{CO}_{2}$ concentration, particularly under warmer soil temperatures. The significant increase in photosynthetic rate and simultaneous decline in stomatal conductance both contributed to the increase in water use efficiency under the elevated $\mathrm{CO}_{2}$. However, such changes did not occur at the low soil temperature. In fact, the water use efficiency declined with increasing soil temperature at the ambient $\mathrm{CO}_{2}$ concentration. At the elevated $\mathrm{CO}_{2}$, in contrast, WUE at warmer soil temperatures $\left(17^{\circ} \mathrm{C}\right.$ and $\left.27^{\circ} \mathrm{C}\right)$ was as high as that at the low soil temperature $\left(7^{\circ} \mathrm{C}\right)$. These results suggest that in the future the photosynthesis of white birch can be increased by warmer soil temperatures without compromising water use efficiency, which occurred under the ambient $\mathrm{CO}_{2}$ concentration. While the soil temperature will most likely increase as the global air temperature increases, further increases in soil temperature can be achieved through silvicultural means, such as site preparation [54] and manipulation of canopy coverage [55] and soil moisture [38]. The lack of significant responses in stomatal conductance to the $\mathrm{CO}_{2}$ elevation under the adverse soil temperature (i.e., $7^{\circ} \mathrm{C}$ ) could be interpreted as that the stomatal conductance at the low soil temperature was already at such a low level that it could not go down any further. However, it is also possible that the low soil temperature reduced root growth and thus water intake and transport, which indirectly affected the stomatal conductance and photosynthesis through its impact on leaf water relations [56].

Our results demonstrate that the tradeoff between water use efficiency and nutrient use efficiency depends on the driving factor or factors that cause changes in their use efficiencies. Generally there is a tradeoff between water use efficiency and nutrient use efficiency [25]. Such a tradeoff exists because within the normal operating range of internal $\mathrm{CO}_{2}$ concentration an increase in stomatal conductance will lead to a linear increase in transpiration rate but a curvilinear (thus smaller) increase in photosynthesis, resulting in a decrease in water use efficiency (ratio of photosynthesis to transpiration). On the other hand, any increase in photosynthesis will result in an increase in nutrient use efficiency since nutrient concentrations in leaves are constant over a short period of time [25]. Physiological acclimations will complicate the issue. In this study, the low soil temperature increased water use efficiency and decreased nitrogen use efficiency under the ambient $\mathrm{CO}_{2}$ concentration. Under the elevated $\mathrm{CO}_{2}$, in contrast, the low soil temperature decreased nitrogen use efficiency without a correspond- ing increase in water use efficiency. Furthermore, the $\mathrm{CO}_{2}$ elevation increased both nitrogen use efficiency and water use efficiency.

The low soil temperature and low P supply did not affect the $\mathrm{CO}_{2}$ elevation induced photosynthetic down regulation in white birch. The hypothesis that the degree of photosynthetic down-regulation in response to $\mathrm{CO}_{2}$ elevation would be greater under low $\mathrm{T}_{\text {soil }}$ and low $\mathrm{P}$ supply was based on the argument that the low $\mathrm{T}_{\text {soil }}$ would suppress the uptake of phosphorus and the resulting lower $\mathrm{P}$ concentration in the foliage would in turn exacerbate the photosynthetic down regulation induced by $\mathrm{CO}_{2}$ elevation because of the low availability of inorganic phosphorus for the Kelvin Cycle of photosynthesis [25]. However, the basis for the hypothesis did not hold in this study. While there was indeed a significant interaction between soil temperature and phosphorus supply on leaf area based $\mathrm{P}$ concentration, soil temperature did not significantly affect foliar $\mathrm{P}$ in the low $\mathrm{P}$ treatment. Furthermore, $\mathrm{P}$ supply did not significantly affect foliage $\mathrm{P}$ in the low soil temperature treatment. Therefore, it is not surprising that the indicators for photosynthetic down regulation did not vary in the way proposed in the hypothesis.

Our results suggest that white birch seedlings responded to low P supplies morphologically by reducing the size and total number of leaves rather than through physiological adjustment. No significant physiological response to low $\mathrm{P}$ supply was detected in this current study. However, we have previously found that the low P supply led to significantly smaller-sized leaves and smaller amount of leaves per tree [57], indicating a different strategy that white birch used in coping with low P supply than some other tree species. For instance, Tissue and Lewis [23] have reported that low P supplies diminish the positive effect of $\mathrm{CO}_{2}$ elevation on light saturated rate of photosynthesis. We offer two explanations for the different responses between the two studies. Firstly, it is possible that different species respond differently. Plants can respond to $\mathrm{P}$ deficits physiologically, morphologically or both [25]. Maybe the prevalent form of response varies with species. Secondly, the range of $\mathrm{P}$ supply was different between the two studies. While the P level in the high $\mathrm{P}$ treatment of [23] was comparable to ours ( 0.50 vs. $0.58 \mathrm{mM} \mathrm{P}_{2} \mathrm{O}_{5}$ ), their low $\mathrm{P}$ supply was much lower than ours ( 0.004 vs. $0.15 \mathrm{mM} \mathrm{P}_{2} \mathrm{O}_{5}$ ). Therefore, it is possible that the low $\mathrm{P}$ level in this study was not low enough to trigger physiological responses and that morphological adjustment is the first line of responses to low $\mathrm{P}$ supplies in white birch.

This study has shown some complicated interactions among soil temperature, nutrient supply and ratios of different nutrient elements. For instance, the $\mathrm{CO}_{2}$ elevation reduced Ka and Pa only at the intermediate and high 
soil temperature while it resulted in lower $\mathrm{Na}$ at all three soil temperatures. Increasing phosphorus supply increased $K_{m}$ but the response of $\mathrm{Na}$ showed different patterns at different soil temperatures. These results demonstrate the complicated nature of interactions among nutrient absorption, allocation, physiological functions and their impact on physiological responses to $\mathrm{CO}_{2}$ elevations under different nutrient regimes. Interactions among several factors are much more difficult to study than the main effects of one or two factors and that probably explains the lack of such data in the scientific literature. However, our data show that such interactions in the real world situations can throw the results of studies with simple designs out of context or relevance under certain circumstances. Of course studies involving one or two treatment factors are very important for understanding the mechanisms of their effects. However, the interactive effects of multiple factors are probably more important for making more realistic predictions of plant responses and therefore warrant more attention in future research. Furthermore, interactions involving more than two factors are difficult to visualize and present. There is an urgent need to develop new techniques or to adopt techniques from other disciplinary areas for analyzing and presenting the results of studies with multiple treatments. Common or standardized expressions of interactive effects should facilitate the comparison of different studies and the utilization of results in further efforts such as modeling and predicting whole plant or ecosystem responses to climate changes.

\section{Acknowledgements}

We appreciate the technical support of Joan Lee, the Greenhouse Manager of Lakehead University, during the course of the experiment.

\section{Funding}

This research was supported by National Science and Engineering Research Council, Canada Foundation for Innovation and Ontario Innovation Trusts grants to Q.L. Dang and Lakehead University Graduate Assistantship to G. Danyagri.

\section{REFERENCES}

[1] A. Rogers, B. U. Fischer, J. Bryant, M. Frehner, H. Blum, C. A. Raines and S. P. Long, "Acclimation of Photosynthesis to Elevated $\mathrm{CO}_{2}$ under Low Nitrogen Nutrition Is Affected by the Capacity for Assimilate Utilization. Perennial Ryegrass under Free-Air $\mathrm{CO}_{2}$ Enrichment," Plant Physiology, Vol. 118, No. 2, 1998, pp. 683-689. http://dx.doi.org/10.1104/pp.118.2.683

[2] H. Saxe, D. S. Ellsworth and J. Heath, "Tree and Forest Functioning in an Enriched $\mathrm{CO}_{2}$ Atmosphere," New Phy- tologist, Vol. 139, No. 3, 1998, pp. 395-436. http://dx.doi.org/10.1046/j.1469-8137.1998.00221.x

[3] P. A. Davey, A. J. Parsons, L. Atkinson, K. Wadge and S. P. Long, "Does Photosynthetic Acclimation to Elevated $\mathrm{CO}_{2}$ Increase Photosynthetic Nitrogen-Use Efficiency? A Study of Three Native UK Grassland Species in OpenTop Chambers,” Functional Ecology, Vol. 13, No. S1, 1999, pp. 21-28. http://dx.doi.org/10.1046/j.1365-2435.1999.00004.x

[4] R. Liozon, F. W. Badeck, B. Genty, S. Meyer and B. Saugier, "Leaf Photosynthetic Characteristics of Beech (Fagus sylvatica) Saplings during Three Years of Exposure to Elevated $\mathrm{CO}_{2}$ Concentration," Tree Physiology, Vol. 20, No. 4, 2000, pp. 239-247. http://dx.doi.org/10.1093/treephys/20.4.239

[5] S. Zhang and Q.-L. Dang, "Effects of Soil Temperature and Elevated Atmospheric $\mathrm{CO}_{2}$ Concentration on Gas Exchange, in Vivo Carboxylation and Chlorophyll Fluorescence in Jack Pine and White Birch Seedlings," Tree Physiology, Vol. 25, No. 5, 2005, pp. 523-531. http://dx.doi.org/10.1093/treephys/25.5.523

[6] S. Zhang and Q.-L. Dang, "Effects of Carbon Dioxide Concentration and Nutrition on Photosynthetic Functions of White Birch Seedlings,” Tree Physiology, Vol. 26, No. 11, 2006, pp. 1457-1467. http://dx.doi.org/10.1093/treephys/26.11.1457

[7] S. P. Long, E. A. Ainsworth, A. Rogers and D. R. Ort, "Rising Atmospheric Carbon Dioxide: Plants FACE the Future,” Annual Review of Plant Biology, Vol. 55, 2004, pp. 591-628. http://dx.doi.org/10.1146/annurev.arplant.55.031903.1416 10

[8] B. Cao, Q.-L. Dang and S. Zhang, "Relationship between Photosynthesis and Leaf Nitrogen Concentration in Ambient and Elevated $\left[\mathrm{CO}_{2}\right]$ in White Birch Seedlings," Tree Physiology, Vol. 27, No. 6, 2007, pp. 891-899.

http://dx.doi.org/10.1093/treephys/27.6.891

[9] R. S. Nowak, D. S. Ellsworth and S. D. Smith, "Functional Responses of Plants to Elevated Atmospheric $\mathrm{CO}_{2}$ : Do Photosynthetic and Productivity Data from FACE Experiments Support Early Predictions?” New Phytologist, Vol. 162, No. 2, 2004, pp. 253-280. http://dx.doi.org/10.1111/j.1469-8137.2004.01033.x

[10] S. Li, S. R. Pezeshki and S. Goodwin, "Effects of Soil Moisture Regimes on Photosynthesis and Growth in Cattail (Typha latifolia),” Acta Oecologica, Vol. 25, No. 1-2, 2004, pp. 17-22.

http://dx.doi.org/10.1016/j.actao.2003.10.004

[11] K. Y. Crous, M. B. Walters and D. S. Ellsworth, "Elevated $\mathrm{CO}_{2}$ Concentration Affects Leaf PhotosynthesisNitrogen Relationships in Pinus taeda over Nine Years in FACE,” Tree Physiology, Vol. 28, No. 4, 2008, pp. 607614. http://dx.doi.org/10.1093/treephys/28.4.607

[12] C. Plassard and B. Dell, "Phosphorus Nutrition of Mycorrhizal Trees,” Tree Physiology, Vol. 30, No. 9, 2010, pp. 1129-1139. http://dx.doi.org/10.1093/treephys/tpq063

[13] D. M. Oosterhuis, A. C. Bibi, E. D. Gonias and M. Mozaffari, "Effect of Phosphorus Deficiency on Cotton Physiology,” AAES Research Series 562, 2007, pp. 35-38. 
[14] M. Chaudhary, J. Adu-Gyamfi, H. Saneoka, N. Nguyen, R. Suwa, S. Kanai, H. El-Shemy, D. Lightfoot and K. Fujita, "The Effect of Phosphorus Deficiency on Nutrient Uptake, Nitrogen Fixation and Photosynthetic Rate in Mashbean, Mungbean and Soybean,” Acta Physiologiae Plantarum, Vol. 30, No. 4, 2008, pp. 537-544. http://dx.doi.org/10.1007/s11738-008-0152-8

[15] A. Brooks, "Effects of Phosphorus Nutrition on Ribulse1,5-Bisphosphate Carboxylase Activation, Photosynthetic Quantum Yield and Amounts of Some Calvin Cycle Metabolites in Spinach Leaves," Australian Journal of Plant Physiology, Vol. 13, No. 2, 1986, pp. 221-237. http://dx.doi.org/10.1071/PP9860221

[16] J. Jacob and D. W. Lawlor, "Dependence of Photosynthesis of Sunflower and Maize Leaves on Phosphate Supply, Ribulose-1,5-Bisphosphate Carboxylase/Oxygenase Activity, and Ribulose-1,5-Bisphosphate Pool Size," Plant Physiology, Vol. 98, No. 3, 1992, pp. 801-807. http://dx.doi.org/10.1104/pp.98.3.801

[17] M. Rao and N. Terry, "Leaf Phosphate Status, Photosynthesis, and Carbon Partitioning in Sugar Beet. IV. Changes with Time Following Increased Supply of Phosphate to Low-Phosphate Plants," Plant Physiology, Vol. 107, No. 4, 1995, pp. 1313-1321.

[18] Z.-H. Lin, L.-S. Chen, R.-B. Chen, F.-Z. Zhang, H.-X. Jiang and N. Tang, " $\mathrm{CO}_{2}$ Assimilation, Ribulose-1,5Bisphosphate Carboxylase/Oxygenase, Carbohydrates and Photosynthetic Electron Transport Probed by the JIP-Test, of Tea Leaves in Response to Phosphorus Supply," BMC Plant Biology, Vol. 9, 2009, p. 43. http://dx.doi.org/10.1186/1471-2229-9-43

[19] H. W. Heldt, C. J. Chon and G. H. Lorimer, "Phosphate requirement for the Light Activation of Ribulosc-1.5Bisphosphate Carboxylase in Intact Spinach Chloroplast," FEBS Letters, Vol. 92, No. 2, 1978, pp. 234-240. http://dx.doi.org/10.1016/0014-5793(78)80761-3

[20] R. C. Leegood, D. A. Walker and C. H. Foyer, "Regulation of the Benson-Calvin Cycle,” In: N. Barber and R. Barker, Eds., Photosynthetic Mechanisms and the Environment, Elsevier, Amsterdam, 1985, pp. 189-258.

[21] U. I. Flügge, K. Fischer, A. Gross, W. Sebald, F. Lottspeich and C. Eckerskorn, "The Triose Phosphate-3Phosphoglyceratephosphate Translocator from Spinach Chloroplasts: Nucleotide Sequence of a Full-Length cDNA Clone and Import of the in Vitro Synthesized Precursor Protein into Chloroplasts,” EMBO Journal, Vol. 8, No. 1, 1989, pp. 39-46.

[22] M. Rao and N. Terry, "Leaf Phosphate Status, Photosynthesis and Carbon Partitioning in Sugar Beet. I. Changes in Growth, Gas Exchange and Calvin Cycle Enzymes," Plant Physiology, Vol. 90, No. 3, 1989, pp. 814-819. http://dx.doi.org/10.1104/pp.90.3.814

[23] D. T. Tissue and J. D. Lewis, "Photosynthetic Responses of Cottonwood Seedlings Grown in Glacial through Future Atmospheric $\left[\mathrm{CO}_{2}\right]$ Vary with Phosphorus Supply,” Tree Physiology, Vol. 30, No. 11, 2010, pp. 1361-1372. http://dx.doi.org/10.1093/treephys/tpq077

[24] T. A. Day, S. A. Heckathorn and E. H. Delucia, "Limitations of Photosynthesis in Pinus taeda (Loblolly Pine) at
Low Soil Temperatures,” Plant Physiology, Vol. 96, No. 4, 1991, pp. 1246-1254.

http://dx.doi.org/10.1104/pp.96.4.1246

[25] H. Lambers, S. F. Chapin III and T. L. Pons, "Plant Physiological Eclogy,” Springer, New York, 2008. http://dx.doi.org/10.1007/978-0-387-78341-3

[26] M. E. Gavito, P. S. Curtis, T. N. Mikkelsen and I. Jakobsen, "Interactive Effects of Soil Temperature, Atmospheric Carbon Dioxide and Soil N on Root Development, Biomass and Nutrient Uptake of Winter Wheat during Vegetative Growth,” Journal of Experimental Botany, Vol. 52, No. 362, 2001, pp. 1913-1923. http://dx.doi.org/10.1093/jexbot/52.362.1913

[27] T. F. Ambebe and Q.-L. Dang, "Low Moisture Availability Inhibits the Enhancing Effect of Increased Soil Temperature on Net Photosynthesis of White Birch (Betula papyrifera) Seedlings Grown under Ambient and Elevated Carbon Dioxide Concentrations,” Tree Physiology, Vol. 29, No. 11, 2009, pp. 1341-1348. http://dx.doi.org/10.1093/treephys/tpp079

[28] T. F. Ambebe and Q.-L. Dang, "Low Moisture Availability Reduces the Positive Effect of Increased Soil Temperature on Biomass Production of White Birch (Betula papyrifera) Seedlings in Ambient and Elevated Carbon Dioxide Concentration," Nordic Journal of Botany, Vol. 28, 2010, pp. 104-111. http://dx.doi.org/10.1111/j.1756-1051.2009.00489.x

[29] T. F. Ambebe, Q.-L. Dang and J. Marfo, "Low Soil Temperature Reduces the Positive Effects of High Nutrient Supply on the Growth and Biomass of White Birch Seedlings in Ambient and Elevated Carbon Dioxide Concentrations,” Botany, Vol. 87, No. 10, 2009, pp. 905912. http://dx.doi.org/10.1139/B09-060

[30] R. O. Teskey, T. M. Hinckley and C. C. Grier, "Effect of Interruption of Flow Path on Stomatal Conductance of Abies amabilis,” Journal of Experimental Botany, Vol. 34, No. 10, 1983, pp. 1251-1259. http://dx.doi.org/10.1093/jxb/34.10.1251

[31] P. G. Blackman and W. J. Davies, "Root to Shoot Communication in Maize Plants of the Effects of Soil Drying," Journal of Experimental Botany, Vol. 36, No. 1, 1985, pp. 39-48. http://dx.doi.org/10.1093/jxb/36.1.39

[32] J. Pastor, R. H. Gardner, V. H. Dale and W. M. Post, "Successional Changes in Nitrogen Availability as a Potential Factor Contributing to Spruce Declines in Boreal North America," Canadian Journal of Forest Research, Vol. 17, No. 11, 1987, pp. 1394-1400. http://dx.doi.org/10.1139/x87-216

[33] E. H. DeLucia, S. A. Heckathorn and T. A. Day, "Effects of Soil Temperature on Growth, Biomass Allocation and Resource Acquisition of Andropogon gerardii Vitman," New Phytologist, Vol. 120, No. 4, 1992, pp. 543-549. http://dx.doi.org/10.1111/j.1469-8137.1992.tb01804.x

[34] D. Paré, Y. Bergeron and C. Camiré, "Changes in the Forest Floor of Canadian Southern Boreal Forest after Disturbance,” Journal of Vegetation Science, Vol. 4, No. 6, 1993, pp. 811-818. http://dx.doi.org/10.2307/3235619

[35] R. S. Folk, S. C. Grossnickle and J. H. Russell, “Gas Exchange, Water Relations and Morphology of Yellow- 
Cedar Seedlings and Stecklings before Planting and during Field Establishment,” New Forest, Vol. 9, No. 1, 1995, pp. 1-20. http://dx.doi.org/10.1007/BF00028922

[36] T. Domisch, L. Finér and T. Lehto, "Effects of Soil Temperature on Biomass and Carbohydrate Allocation in Scots Pine (Pinus sylvestris) Seedlings at the Beginning of the Growing Season,” Tree Physiology, Vol. 21, No. 7, 2001, pp. 465-472. http://dx.doi.org/10.1093/treephys/21.7.465

[37] P.J. Aphalo, M. Lahti, T. Lehto, T. Repo, A. Rummukainen, H. Mannerkoski and L. Finér, "Responses of Silver Birch Saplings to Low Soil Temperature," Silva Fennica, Vol. 40, No. 3, 2006, pp. 429-442.

[38] G. B. Bonan and H. H. Shugart, "Environmental Factors and Ecological Processes in Boreal Forests," Annual Review of Ecology and Systematics, Vol. 20, 1989, pp. 1-28. http://dx.doi.org/10.1146/annurev.es.20.110189.000245

[39] J. C. Zasada, A. G. Gordon, C. W. Slaughter and L. C. Duchesne, "Ecological Considerations for the Sustainable Management of the North American Boreal Forests," IIASA Interim Report IR-97-024/July 67, 1997.

[40] R. Z. Man, G. J. Kayahara, Q.-L. Dang and J. A. Rice, “A Case of Severe Frost Damage Prior to Budbreak in Young Conifers in Northeastern Ontario: Consequence of Climate Change?” The Forestry Chronicle, Vol. 85, No. 3, 2009, pp. 453-462.

[41] T. Landis, R. Tinus, S. McDonald and J. Barnett, "The Container Nursery Manuals. Volume 2: Containers and Growing Media,” Agricultural Handbook 674, USDA Forest Service, Washington DC, 1993.

[42] S. Cheng, Q.-L. Dang and T.-B. Cai, “A Soil Temperature Control System for Ecological Research in Greenhouses,” Journal of Forest Research, Vol. 5, No. 3, 2000, pp. 205-208. http://dx.doi.org/10.1007/BF02762403

[43] R. M. Burns and B. H. Honkala, "Silvics of North America Volume 2, Hardwoods,” Agriculture Handbook 654, USDA Forest Service, Washington DC, 1990, 877p.

[44] D. A. Horneck and R. O. Miller, "Automated Combustion Method with LECO-CNS. Determination of Total Nitrogen in Plant Tissue,” In: Y. P. Kalra, Ed., Handbook of Reference Methods for Plant Analysis, CRC Press LLC, Boca Raton, 1998, pp. 75-83.

[45] R. C. Munter and R. A. Grande, "Plant Analysis and soil extracts by ICP-atomic emission spectrometry,” In: R. M. Barnes, Ed., Developments in Atomic Plasma Spectrochemical Analysis, Heyden and Son, Ltd., London, 1981, pp. 653-672.

[46] R. A. Miller, "Nitric-Perchloric Acid Wet Digestion in an Open Vessel,” In: Y. P. Kalra, Ed., Handbook of Reference Methods for Plant Analysis, CRC Press LLC, Boca Raton, 1998, pp. 57-61.

[47] C. R. Hicks and K. V. Turner, "Fundamental Concepts in the Design of Experiments,” 5th Edition, Oxford University Press, New York, 1999.

[48] M. Martin, K. Gavazov, C. Körner, S. Hättenschwiler and C. Rixen, "Reduced Early Growing Season Freezing Resistance in Alpine Treeline Plants under Elevated Atmospheric $\mathrm{CO}_{2}$," Global Change Biology, Vol. 16, No. 3, 2010, pp. 1057-1070. http://dx.doi.org/10.1111/j.1365-2486.2009.01987.x

[49] D. A. Clark and D. B. Clark, "Life History Diversity of Canopy and Emergent Trees in a Neotropical Rain Forest," Ecological Monographs, Vol. 62, No. 3, 1992, pp. 315344. http://dx.doi.org/10.2307/2937114

[50] C. D. Canham, "Different Response to Gaps among Shade-Tolerance Tree Species,” Ecology, Vol. 70, No. 3, 1989, pp. 549-550. http://dx.doi.org/10.2307/1940200

[51] T. F. Ambebe, Q.-L. Dang and J. Li, "Low Soil Temperature Inhibits the Effect of High Nutrient Supply on Photosynthetic Response to Elevated Carbon Dioxide Concentration in White Birch Seedlings," Tree Physiology, Vol. 30, No. 2, 2010, pp. 234-243. http://dx.doi.org/10.1093/treephys/tpp109

[52] K. Y. Crous, P. B. Reich, M. D. Hunter and D. S. Ellsworth, "Maintenance of Leaf N Controls the Photosynthetic $\mathrm{CO}_{2}$ Response of Grassland Species Exposed to 9 Years of Free-Air $\mathrm{CO}_{2}$ Enrichment," Global Change Biology, Vol. 16, No. 7, 2010, pp. 2076-2088. http://dx.doi.org/10.1111/j.1365-2486.2009.02058.x

[53] H.-M. Ro, P.-G. Kim, I.-B. Lee, M.-S. Yiem and S.-Y. Woo, "Photosynthetic Characteristics and Growth Responses of Dwarf Apple (Malus domestica Borkh. cv. Fuji) Saplings after 3 Years of Exposure to Elevated Atmospheric Carbon Dioxide Concentration and Temperature," Trees, Vol. 15, No. 4, 2001, pp. 195-203. http://dx.doi.org/10.1007/s004680100099

[54] G. Orlander, P. Gemmel and J. Hunt, "Site Preparation: A Swedish Overview," Government of Canada, Province of British Columbia, 1990, p. 62.

[55] D. M. Smith, B. C. Larson, M. J. Kelty and P. M. S. Ashton, "The Practice of Silviculture: Applied Forest Ecology,” 9th Edition, John Wiley and Sons, New York, 1997.

[56] A. Sellin and P. Kupper, "Effects of Light Availability versus Hydraulic Constraints on Stomatal Responses within a Crown of Silver Birch,” Oecologia, Vol. 142, No. 3, 2005, pp. 388-397. http://dx.doi.org/10.1007/s00442-004-1748-3

[57] T. F. Ambebe, G. Danyagri and Q.-L. Dang, "Low Soil Temperature Inhibits the Stimulatory Effect of Elevated $\left[\mathrm{CO}_{2}\right]$ on Height and Biomass Accumulation of White Birch Seedlings Grown under Three Non-Limiting Phosphorus Conditions," Nordic Journal of Botany, Vol. 31, No. 2, 2013, pp. 239-246. http://dx.doi.org/10.1111/j.1756-1051.2012.01211.x 